\title{
Multimedia Application Material for Speech Skill
}

\author{
Abdul Hafidz Zaid ${ }^{1}$, Imam Bahroni ${ }^{2}$ and Ahmad Khaerurrozikin $\mathrm{S}^{3}$ \\ \{abuafadh@unida.gontor.ac.id'1, mas.bahroni@gmail.com², \\ khaerurrozikin.ahmad@mhs.unida.gontor.ac.id ${ }^{3}$ \} \\ Department of Arabic Language Teaching Postgraduate Program, \\ University of Darussalam Gontor, Jl. Raya Siman No.Km. 6, Dusun I, Siman, Kabupaten Ponorogo, \\ Jawa Timur 63471
}

\begin{abstract}
In context of learning Arabic, speech is a basic skill that must be mastered by the students, and it's one of the final objectives of foreign for language learning, Because students are required to be able to communicate both with the teacher and friends. However, the problems that occur at this time are Non KMI students (Kulliyatul Muallimin Islamiyah) or often called Non Gontor graduated, have not be able to express or compose sentences within their minds even though they have studied for a year at Arabic language hostel Darussalam Gontor University. To solve this kind of problem, the researchers compile teaching materials using image media as an appropriate tool to facilitate students in improving their ability to express or compose sentences in their minds.
\end{abstract}

Keywords: Media, Image Material, Speaking Skill

\section{Introduction}

Arabic is one of the languages which used by many groups of people around the world including Indonesia, as is the case in Islamic boarding schools and other Islamic institutions that are used as official languages in communicating in daily life, even Arabic is also used as the language of instruction in lectures, the goal is to realize students who are active in communicating Arabic verbally.

The University of Darussalam Gontor is a university that requires students to speak Arabic both in lectures and outside of lectures because in the context of Arabic learning, speaking includes basic skills that must be mastered by students and is one of the final objectives of Foreign Language learning. For this reason, the University of Darussalam Gontor Language Center established the Arabic language hostel program for students who have no language skills, and this Arabic language hostel program is only one year, and this time is relatively short for beginner students, to maximize speaking learning, researchers use the picture as a media in speaking learning.

Based on the problems elaborated above, the researchers used speech skill learning by using picture media as an alternative to improving speech skill for students at language hostel University of Darussalam Gontor. How to learn speech skill by using picture media will figure it out in this paper. 


\section{Definition of Learning Media}

The word media drives from the Latin word means "medius" and is a plural form of the word medium which literally means middle, intermediary or introduction In general,[1, p. 5] media are all forms of intermediaries to spread, carry or convey something message and ideas to the recipient so that they can stimulate the thoughts, feelings, and interests and attention of students in such a way that the learning process occurs.[2, p. 7] Thus the media is an additional function that is as a tool to create an effective teaching learning situation, in addition to completing the learning process so that it will attracts the attention of students more[3, p. 134].

The term media is extremely popular in the field of communication, the learning process is essentially a communication process. In the communication process there are important components that play their role, namely curriculum and students.[4, p. 125] In order for the communication process between education and students to run well and smooth or take place effectively and efficiently need a tool called learning media.

From this definition, it can be concluded that learning media is an educational tool that can be used as an intermediary in the process of stimulating students' thoughts, feelings and wishes, so that it can encourage learning that is an integral part of the educational process.

\section{The Important of Media in Teaching}

The teacher is the spearhead and the central point for realizing the progress of education in schools and colleges, therefore the media is needed to facilitate students in mastering subject matter with the aim of generating interest, motivation, creativity and increasing student activity and making lessons meaningful which will ultimately improve results student learning.

In order for learning to improve learning outcomes, one of the things that teachers do is to make the selection of appropriate learning media so as to improve students' competencies and abilities in learning. Herein lies the importance of the media as an intermediary or channel that helps students in learning, in other words that instructional media is a kind of tool to assist students in refining and clarifying the meaning of words, sentences, concepts of thought and guidance to acquire skills. Based on the explanation above it can be seen that learning media can enhance the quality of teaching and learning process which in turn can improve the quality of student learning outcomes.

\section{Definition of Speech}

The Arabic subject is a subject which is directed to encourage developing, and fostering abilities and fostering positive attitudes towards Arabic both by understanding the conversations of others and as a means of oral and written communication as well as exchanging experiences, expressing opinions or understanding what delivered by others. For that in a person is very necessary language skills to be able to express what they think and feel.

Speaking skill's related to language is the ability to pronounce sounds or a word that has meaning.[5, p. 792] juz 2 Whereas according to the term language is one's ability to express what is in his mind or express,[6, p. 12] express and convey ideas and feelings. As Acep Hermawan said "The mastery of speaking is essentially the ability to produce the sounds of articulation or words to express and convey thoughts, ideas, and feelings.[7, p. 135]

Based on the above opinion that language is a skill used by everyone in everyday life. This skill requires a lot of practice, which is basically not a process of the ability of intellectuality but includes the ability to receive and send messages from the speaker (Mutakallim) with the interlocutors. 
Therefore, speaking is one's ability to pronounce the articulation of Arabic sounds, for that the teaching of Arabic for non-Arabs in the initial stages aims to be able to pronounce sounds, be able to express ideas with complete sentences in various conditions, be able to speak with simple or short sentences, and capable speak fluently around general topics, such as about daily life, sports, kitchen, class, and so on.

According to the variety of definitions above, it can be concluded that speaking activities both within lectures and outside of lectures should have aspects of communication that are between the speaker and the listener reciprocally. In this way, speaking exercises must first be based on listening skills, speaking skills, and mastery of vocabulary.

\section{The Objectives of Speaking Learning}

Speaking skills are a very important field of learning, in addition to other language skills, because students' speaking skills will greatly affect student college assessments. In the educational environment, students are required to be skilled at speaking during the learning process, when in discussion activities students are required to be skilled at expressing opinions, defending opinions, refuting the opinions of other students or being able to influence other students to follow their thinking lines.

Apart from this, it can recognize that the purpose of learning speech is how a persona able to communicate with others, while the other objectives are; firstly, Getting used the student participants to pronounce expressions clearly, fluent and contain complete meaning. Secondly, familiarize students with thinking and speaking in a systematic Arabic language. Thirdly, too accustomed students with using sentences or expressions that suit a variety of contexts. Fourth, in order students are accustomed to using sentences that are full of meaning, and beautiful in language style bay following standard Arabic rules of fluent. Fifth, making one's ability to express what is in himself, expressing what he saw with a good expression, and also makes a way of thinking in using the sentence correctly because of the correct expression of words that prevent a person from failure.

\section{Model of Speaking Skill}

In speaking Learning, there are various models and of speech exercises that have been developed by language teachers. Each approach or method gives emphasizes to certain techniques. The audio-lingual method, for example, emphasizes the need to learn to memorize the dialogue model before entering into free dialogue. While the communicative method emphasizes the understanding of the dialogue model including the function of each expression and the context or situation, it then goes straight into the actual communication exercise. Among the models of conversation training as follows:

\section{a. Stories Telling}

Giving assignments to students to tell stories is one way to find out the ability to speak directly. To be able to tell stories, there are two things students must master, namely the elements of how to tell stories and how to choose the language and what elements are told. The accuracy, smoothness, and clarity of the story will show students' speaking ability.[8, p. 289] 
As explained above, storytelling is based on the stimulation of drawings, besides that, it can also be in the form of experiences, such as recreation, pleasant experiences, sad experiences and so on.[9, p. 57] however, these stimuli can be applied to various levels of elementary school students up to the high school level, but the teaching material notes must be adjusted to the level of development of the student concerned. Many books are told by teachers, even up to the level of tertiary education. From this, it can be seen that speaking learning with picture media will make it easy for students to compose sentences properly and correctly.

\section{b. Talking Based on the Picture}

To reveal the students' speaking ability in a language, pictures can be used as a stimulus for good conversation. Stimulation in the form of images is very good to be used in children of primary school age or early-stage foreign language students. However, image stimulation can also be used on students whose language abilities are higher depending on the shape of the drawing used itself. Pictures that are intended as stimulation of the conversation are not loose pictures that are not related to one another. However, one picture with another picture is interrelated.

Then after learning later, students are asked to name the object, either by the examiner showing the pictures in question or asking questions such as "what is this picture?" Or "what activity is in the picture?" and so on. Assignments like the one above do not force students to show their ability to speak, both concerning linguistic accuracy and extra-linguistic elements. The picture presented to students is a picture that contains activities, which reflect certain intentions or ideas. The picture in question is a picture that has a purpose or story that shows an event.

Furthermore, to teaching a speaking effectively, it is necessary to do a thorough analysis and consideration in choosing the approach and determining the method of learning. Here there is an approach that can be used as a basis for determining the method or technique of speaking learning, such as the listening-oral, approach communication, the listening-seeing approach including:

a. This approach minimizes the needs of students in writing in the form of explanations and others because of the clarity of images and their variations automatically guide students to verbally express the meanings contained in the picture.

b. The process of learning with this approach focuses on the use of the senses of hearing, vision, and pronunciation. The use of these senses regularly and continuously can train the smoothness of students in practice of speaking.

c. This approach can stimulate and increase students' motivation to continue and practice speaking with some of the expressions they have learned in the listening learning phase. Thus students feel that they have learned something useful and be able to practice it. 
d. This approach can be used as a reference for the use of other techniques such as direct techniques, drama techniques, question and answer techniques, and so on. It is can also be used in activities such as camping, recreation, discussion, receptions, and contest activities.

\section{Steps of Speaking Learning}

There are several steps can be utilized by a teacher when teaching speaking skills, including:

Before the teacher starts to teach, the teacher firstly presents a picture story that is in accord with students' reasoning ability and language, so that students have no difficulty in understanding it.

b. After that, the teacher then reads the text of the pictorial story with a clear reading until the text is completely readout.

c. And then the teacher allows students to discuss the themes they have heard and seen.

d. Each picture is related to one another. Then afterward, students are asked to read the story as exemplified by the teacher, then after that, the teacher asks one of the students to explain the contents of the story by following what he knows in the language he can.

e. A teacher displays a collection of pictures; pictures one to the second, third and so on the picture are related. Then a teacher asks the student to stand in front of his friend to explain the connection between one picture and another.[10, p. 261], [11, p. 140], [12, pp. 298-299], $[13$, p. 93], [14, p. 65]

Example: when students come to class in the morning, they then immediately divide assignments, some have swept the floor with a broom, some clean the table with a feather duster, some clean the window, and others clean the blackboard with an eraser. With this division makes the entire work quickly and easily, as stated in wisdom, unity is the basis for success.

\section{Using Picture Media to Increasing Speaking Learning}

In learning of speech skills for the beginner level, including students at language hostel Darussalam University of Gontor, researchers found the problems in teaching speaking skills. The mistake is that students are still weak and have difficulty in composing a sentence because one of the causes is inadequate vocabulary, besides that it is also pure because they cannot arrange sentences even though they have an adequate vocabulary.

For this reason, researchers use instructional media with pictures, the aim is to help and facilitate students to be able to compose sentences and later they can speak Arabic well. Because with this picture, according to Abdul Majid Sayyid Ahmad Mansur, "Media of picture can help beginner-level students to make a sentence by following an explanation from a teacher.'[15, p. 157] In addition, Umar As-Sodiiq Abdullah said that the picture has three roles: First, the picture will be accompanied by a text story in Arabic. The aim is to describe the 
meaning of the title of the text. Second, it helps students to remember the language lessons they have learned before. And the third is used to explain new vocabulary.[16, p. 173]

This learning media is in the form of a picture in the form of a story, why is that, because a picture story can be in the form of a written event that has already taken place or in the form of a fantasy that arises from one's artistic imagination. The steps on how to teach language to students with this picture story are as follows:[17, p. 619][17, p. 715]

Firstly: the teacher displays a collection of illustrated stories after that is discussed with questions related to the picture or students are asked to describe what is seen in the picture freely. Secondly, give the students some stories that fit their abilities and conditions that student recognizes, afterward the teacher asks the students to analyze the stories that have been told and then tell them to retell it again.

From the explanation above it can be seen that the picture has a very big influence in remembering what has happened before, both in terms of the events they experienced, or the events they saw. Then the pictures form a story that is accompanied by a text, in the text then has a vocabulary that will help students in forming a sentence so that it takes the form of a speech. Therefore, researchers see that this illustrated story will be an appropriate tool to improve students' abilities in the field of speaking skills.

\section{The Value of Analytical Speaking Learning by Using Picture Media}

After researchers completed of speaking study with media of picture for students at language hostel. Darussalam University of Gontor, the researchers then presented the results of the questionnaire to see the effect of using media of picture in increasing of speaking learning students of language hostel Darussalam University, researchers used a closed questionnaire to measure the extent The results of using image media, the results will be explained in the following: 
Questionnaire Results for Students of Sakan Arab University of Darussalam

From the description of the chart above it is clear that:

\begin{tabular}{|c|c|c|c|c|c|c|c|c|}
\hline \multirow[b]{2}{*}{ 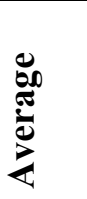 } & \multirow[b]{2}{*}{$\stackrel{\tilde{T}}{\stackrel{5}{0}}$} & \multicolumn{5}{|c|}{ Number of Percentage } & \multirow[b]{2}{*}{ Questions } & \multirow[b]{2}{*}{$\stackrel{\circ}{Z}$} \\
\hline & & $\mathbf{E}$ & D & $\mathbf{C}$ & B & $\mathbf{A}$ & & \\
\hline$\% 90$ & 45 & - & - & - & 5 & 5 & $\begin{array}{l}\text { Does the use of Grammar help you } \\
\text { arrange Arabic sentence? }\end{array}$ & 1 \\
\hline$\% 84$ & 42 & - & - & - & 8 & 2 & $\begin{array}{c}\text { Does a using Picture easily helpful in } \\
\text { expressing Arabic sentences? }\end{array}$ & 2 \\
\hline$\% 94$ & 47 & - & - & - & 3 & 7 & $\begin{array}{c}\text { Does a using Pictures make students easy } \\
\text { in compiling the vocabulary into Arabic } \\
\text { sentences and be able to know it uses in } \\
\text { speaking? }\end{array}$ & 3 \\
\hline$\% 96$ & 48 & - & - & - & 2 & 8 & $\begin{array}{c}\text { Does the use of picture media helps } \\
\text { students understand the subject of } \\
\text { Maharatul Kalam? }\end{array}$ & 4 \\
\hline$\% 82$ & 41 & - & - & 1 & 7 & 2 & $\begin{array}{c}\text { Does a using picture medium help } \\
\text { students in practising speaking Arabic? }\end{array}$ & 5 \\
\hline$\% 98$ & 49 & - & - & - & 1 & 9 & $\begin{array}{c}\text { Does the use of picture media make } \\
\text { students easy in telling stories? }\end{array}$ & 6 \\
\hline$\% 80$ & 40 & - & - & 1 & 8 & 1 & $\begin{array}{l}\text { Does the use of picture media can } \\
\text { encourage students to speak Arabic } \\
\text { continuously? }\end{array}$ & 7 \\
\hline$\% 94$ & 47 & - & - & 1 & 1 & 8 & $\begin{array}{l}\text { Does the use of pictures have an effect in } \\
\text { remembering the lessons for a long time? }\end{array}$ & 8 \\
\hline$\% 90$ & 45 & - & - & 0 & 5 & 5 & $\begin{array}{l}\text { Does the use of picture media make } \\
\text { learning of maharatul kalam enjoyable } \\
\text { during the learning process? }\end{array}$ & 9 \\
\hline$\% 92$ & 46 & - & - & 1 & 2 & 7 & $\begin{array}{l}\text { Does the use of picture media in learning } \\
\text { maharatul kalam makes students have a } \\
\text { lot of practice to speak? }\end{array}$ & 10 \\
\hline$\% 96$ & 48 & - & - & - & 2 & 8 & $\begin{array}{l}\text { Does the use of picture media eliminate } \\
\text { boredom in learning maharatul kalam? }\end{array}$ & 11 \\
\hline
\end{tabular}

1. The average score of the questioner for the first problem is $90 \%$ (Strongly agreed) that students agree that the use of pictures can help in expressing Arabic sentences. 
2. The average score for the second question is $84 \%$ (agreed) Shiva agrees that the use of pictures helps Shiva easily express Arabic sentences.

3. The results of the average value of the questioner for the third question $94 \%$ (Strongly agreed) students agreed that the use of images can help students in combining vocabulary into Arabic sentences and can find out how they are used in speaking.

4. The average value of the questioner for the fourth question $96 \%$ (Strongly agreed) students agreed that the use of pictures can help students in understanding speaking lessons without difficulty.

5. The average value of the questioner for the fifth question $82 \%$ (agree) students agree that the use of pictures can help students practice speaking Arabic.

6. The average value of the questioner for the sixth question $98 \%$ (Strongly agreed) students agreed that the use of pictures can help students in facilitating students in telling stories using Arabic.

7. The results of the average questioner score for the seventh question $80 \%$ (agree) students agree that the use of pictures can encourage students to continue to speak Arabic?

8. The average value of the questioner for the future questions $94 \%$ (Strongly agree) students agree that the use of pictures can help students remember the lesson for a long period of time.

9. The results of the average questioner score for the ninth question $90 \%$ (Strongly agreed) students agreed that the use of pictures made speaking learning enjoyable during the learning of speaking took place.

10. The average value of the questioner for the tenth question of $92 \%$ (Strongly agreed) students agree that the use of pictures makes students have a lot of practice to talk.

11. The average value of the questioner for future questions $96 \%$ (Strongly agree) students agree that the use of pictures can eliminate boredom in speaking learning.

In general, the overall value of the questionnaire the researcher have shared with all Sakan Araby students with grades:

Result Rating Average: $\frac{241}{285} \mathrm{X} 100 \%: 84.5 \%$

The average value of $84.5 \%$ shows that students agree with the use of pictures, because its use is more effective in improving speaking lessons for students at Arabic hostel Darussalam University of Gontor ponorogo. For that from the above explanation it is clear that the process of using images in improving speaking skills has a positive effect, with the argument that students are able to express Arab's sentences well, and also students are able to communicate among their peers.

\section{The Results of Value Before and After}

After the researchers conducted a field experiment by using instructional media on students at Arabic hostel Darussalam University of Gontor. The researcher wants to know the effectiveness of instructional media using images in improving speaking learning. In this section, values will be presented before and after learning using picture media:

\begin{tabular}{|l|c|c|c|}
\hline \multirow{2}{*}{ No } & Name of Students & \multicolumn{2}{c|}{ Value Result } \\
\cline { 3 - 4 } & & The value before & The value after \\
\hline 1 & Atha Mahdi Muhammad & 62 & 86 \\
\hline
\end{tabular}




\begin{tabular}{|l|l|c|c|}
\hline 2 & Abdul Haris Al-Farisi & 55 & 76 \\
\hline 3 & Yosi Kurnia Yudatama & 66 & 91 \\
\hline 4 & Hanif Mujahidin & 62 & 79 \\
\hline 5 & Ichsan Nurfalan Gunawan & 55 & 73 \\
\hline 6 & Jamal Muhroji & 61 & 79 \\
\hline 7 & Robbiy Marten Abdullah & 70 & 95 \\
\hline 8 & Meirando Rukhuz & 62 & 78 \\
\hline 9 & Bagus Yudistira & 58 & 81 \\
\hline 10 & Eriamon Efriadi & 60 & 77 \\
\hline 11 & Muhammad Syamsul Huda & 62 & 85 \\
\hline 12 & Agung Purnomo Djati & 61 & 74 \\
\hline 13 & Muhammad Syaiful Haq & 62 & 73 \\
\hline 14 & M.Fadil Hidayatullah & 60 & 75 \\
\hline 15 & M.Rizki Fadillah & 60 & 79 \\
\hline 16 & Sigit Purnomo & 59 & 68 \\
\hline 17 & Khairul Anam & 63 & 77 \\
\hline 18 & Muhammad Fadil & 60 & 80 \\
\hline 19 & Abdillah Fauzan & 60 & 85 \\
\hline 20 & Rahmat Maulana & 70 & 93 \\
\hline & Total number & 1228 & 1604 \\
\hline
\end{tabular}

In analyzing the results of the scores before and after, researchers used the SPSS program,

\begin{tabular}{|c|c|c|c|c|c|c|c|c|}
\hline & \multicolumn{5}{|c|}{ Paired Differences } & \multirow[t]{3}{*}{$\mathrm{t}$} & \multirow[t]{3}{*}{$\mathrm{Df}$} & \multirow{3}{*}{$\begin{array}{l}\text { Sig. (2- } \\
\text { tailed) }\end{array}$} \\
\hline & \multirow[t]{2}{*}{ Mean } & \multirow[t]{2}{*}{$\begin{array}{c}\text { Std. } \\
\text { Deviation }\end{array}$} & \multirow[t]{2}{*}{$\begin{array}{l}\text { Std. Error } \\
\text { Mean }\end{array}$} & \multicolumn{2}{|c|}{$\begin{array}{l}\text { 95\% Confidence } \\
\text { Interval of the } \\
\text { Difference }\end{array}$} & & & \\
\hline & & & & Lower & Upper & & & \\
\hline $\begin{array}{ll}\text { Pair } & \text { PRE TEST - } \\
1 & \text { POST TEST }\end{array}$ & $\begin{array}{r}18.800 \\
00\end{array}$ & 4.84062 & 1.08240 & -21.06548 & -16.53452 & $\begin{array}{r}17.36 \\
9\end{array}$ & 19 & .000 \\
\hline
\end{tabular}

From the above table it is clear that the t-value is 17.36 greater than the t-table of 2.086 , with this it is clear that the use of most learning media with images is more effective. For this reason, if we look at the information above, the researcher can conclude that students like to use the media of images in speaking learning, because it provides convenience.

\section{Conclusion}

Based on the results of research that has been done, it can be concluded that, speaking learning by using picture media for students of Arabic hostel University of Darussalam Gontor first: can help and facilitate them in understanding the material taught by the teacher. Secondly, they can compile the sentence becomes a story and can be retold in front of their friends. Third, speaking learning with picture media makes Arabic hostel students can remember the lessons 
delivered by the teacher for a long time, fourth, speaking learning with picture media are able to increase the value of speaking lessons, could be seen from the table above it is clear that the value t-is 17.36 larger than t-Table 2.086, for this prove it is clear that using of learning media by using pictures is more effect.

[1] Azhar Arsyad, Bahasa Arab dan Metode Pengajarannya, 3rd ed. Yogyakarta: Pustaka Pelajar, 2010.

[2] A. S and Sadarman, Media Pendidikan Pengertian dan Pemanfaatan. jakarta: Raja Grafindo, 2006.

[3] A. Z. Syaiful Bahri Djamarah, Strategi Belajar Mengajar, 4th ed. jakarta: Raja Grafindo, 2010. 
[4] Munir, Perencanaan Sistem Pengajaran Bahasa Arab. .

[5] M. A. Al-Arabiyah, Kamus Mu'jam al-Washit. Al-Qahirah: Darul Ma'arif, 1972.

[6] A. A. A. Idris, Daurah Maharatu al-Kalam Ta'lim al-Allughah al-Arabiyah Linnatiqin Bighairiha Yunadzzimuha Wa Yanfazuha. Jami'ah Darussalam Islamiyah Markaz Abdul Aziz, 2014.

[7] A. Hermawan, Metodologi Pembelajaran Bahasa Arab, IV. Bandung: PT.REMAJA ROSDAKARYA, 2014.

[8] B. Nurgiyantoro, Penilaian Dalam Pengajaran Bahasa dan Sastra, I. Yogyakarta: BPFE-Yogyakarta, 2001.

[9] H. . A. Hamid, Mengukur Kemampuan Bahasa Arab Untuk Studi Islam, II. Malang: UIN- Malang Press, 2013.

[10] H. J. Al-Khalifah, Fusuul Fi Tadris Allughah Al-Arabiyah Ibtidai Mutawassit Tsanawi. Riyad: Maktabah Arrosyid.

[11] F. H. A. Al-Hijai, Asalib Wa Turuq Tadris Al-Lughah Al-Arabiyah Wa I'dadi Durusiha Al-Yaumi. Oman: Darrul Manahij Linnasyr Wa Tauzi.

[12] A. F. H. Al-Bahjah, Ushul Tadris Al-Arabiyah Bainannazriyah Wa Al-Mumarasah. .

[13] A. W. Rosyidi and M. Ni'mah, Memahami Konsep Dasar Pembelajaran Bahasa Arab. II: UIN MALIKI PRESS Anggota IKAPI, 2012.

[14] R. Zaenuddin, S. Gumiandari, B. Imam, H. Saefullah, and Sumanta, Metodologi dan Strategi Alternatif, I. Yogyakarta: Pustaka Rihlahgroup, 2005.

[15] A. M. S. A. Mansur, Saykuluji Al-Wasaail At-Ta'limiyah Wa Wasaail Tadris Al-Lughah Al-Arabiyah. Al-Ma'arif.

[16] U. A. Abdullah, Ta'lim Al-Lughah Al Arabiyah Linnatiqin Bighairiha At-Turuq -AlAsalib-Al-Wasaail. Afrikiya: Afrikiya: Addarul Alamiyah 'Amid Ma'had Al-Lughah Al Arabiyah Jaami'ah Ifrikiya Al Alamiyah.

[17] M. S. Samak, Fannu at-T Attadris Littarbiyah Al Lughah Al Arabiyah Wa Intiba 'atiha Al 'amaliyah. Al-Maktabah Al Misriah, 1979. 